\title{
VARIASI PENGARUH PROGRAM BERAS MISKIN (RASKIN) TERHADAP KONSUMSI MAKANAN RUMAH TANGGA
}

\section{THE HETEROGENEOUS EFFECT OF “RICE FOR THE POOR” PRO- GRAM (RASKIN) ON HOUSEHOLD FOOD CONSUMPTION}

\author{
Syahril $^{1 *}$, Randi Kurniawan ${ }^{1^{* *}}$ \\ ${ }^{1}$ LOGOV Celebes, Makassar, Sulawesi Selatan, Indonesia \\ *syahril.philosopia84@gmail.com; **randikurniawan512@gmail.com
}

\begin{abstract}
Abstrak
Beras untuk rumah tangga miskin (Raskin) merupakan salah satu program pengentasan kemiskinan di Indonesia yang sudah berlangsung sejak 21 tahun lalu, namun pengaruhnya terhadap konsumsi rumah tangga masih menimbulkan perdebatan. Studi ini bertujuan untuk mengkaji adanya variasi pengaruh program Raskin terhadap konsumsi makanan pada berbagai kelompok rumah tangga berdasarkan pengeluaran dengan menggunakan data Indonesia Family Life Survey (IFLS) tahun 2014. Model estimasi yang digunakan adalah regresi multivariat dengan metode Ordinary Least Square (OLS). Hasil penelitian menunjukkan bahwa pada rumah tangga penerima Raskin, kelompok paling miskin ( $20 \%$ terbawah) secara relatif mengalokasikan sumber daya lebih banyak untuk konsumsi beras dan makanan pokok dibanding kelompok kurang miskin (20\% teratas). Sementara itu, kelompok rumah tangga kurang miskin secara relatif membelanjakan uang lebih banyak untuk makanan bernutrisi, seperti telur dan susu, daging dan ikan. Namun, proporsi konsumsi rokok dan alkohol juga lebih tinggi pada rumah tangga kurang miskin. Temuan studi ini mendorong perlunya perbaikan sasaran program Raskin karena manfaatnya lebih banyak dinikmati oleh rumah tangga kurang miskin dibanding rumah tangga paling miskin.
\end{abstract}

Kata Kunci: konsumsi, raskin, IFLS

Klasifikasi JEL: 138, 132, E21

\begin{abstract}
Rice for poor households (Raskin) is one of poverty alleviation programs in Indonesia that lasted 21 years, but its influence on household consumption is still causing debate. This study aims to examine the variations in the influence of the Raskin program on food consumption in various household groups based on expenditure using the 2014 Indonesian Family Life Survey (IFLS) data. The estimation model used is multivariate regression using the Ordinary Least Square (OLS) method. The results showed that in Raskin recipient households, the poorest groups (the lowest 20\%) allocated more resources to consume rice and staple food than the less poor groups (the top 20\%). Meanwhile, groups of less poor households relatively spend more on nutritious foods, such as eggs and milk, meat and fish. However, the proportion of cigarette and alcohol consumption is also higher in less poor households. The findings of this study encourage the need to improve the target of the Raskin program because the benefits are more enjoyed by less poor households than the poorest households.
\end{abstract}

Keyword: consumption, raskin, IFLS

JEL Classification: 138, 132, E21

\section{PENDAHULUAN}

Sebagai salah satu upaya mengatasi dampak negatif dari krisis ekonomi tahun 1998, pemerintah meluncurkan bantuan pangan beras atau dikenal sebagai Operasi Pasar Khusus (OPK) di bawah program Jaring Pengaman Sosial (JPS). Pada awal penerapanya, OPK memberi bantuan kepada 9,29 juta rumah tangga yang masuk dalam kategori keluarga pra-sejahtera dan keluarga sejahtera 1 berdasarkan data Badan Kependudukan dan Keluarga Berencana Nasional (BKKBN). Program OPK berlangsung hingga tahun 2001, kemudian berganti nama menjadi bantuan beras untuk 
rumah tangga miskin (Raskin) sekaligus menjadi bagian dari program perlindungan sosial rumah tangga miskin, tidak lagi sebagai program darurat penanggulangan dampak krisis ekonomi (Hastuti dkk., 2008). Program ini masih dilanjutkan oleh pemerintah sampai saat ini dengan mengganti nomenklaturnya menjadi Bantuan Sosial (Bansos) Beras Sejahtera (Rastra) yang merupakan bagian dari program Bansos Pangan.

Hingga saat ini, pemerintah terus memperluas skala dan jangkauan penerima Raskin. Tahun 2017, pemerintah menetapkan sebanyak 14,21 juta Rumah Tangga Sasaran (RTS) atau naik 53\% sejak tahun 1998. Sebagai konsekuensi bertambahnya RTS, pemerintah juga menaikkan jumlah alokasi Raskin rerata menjadi 3,07 juta ton dalam kurun waktu 2010-2017, dimana setiap RTS menerima Raskin bervariasi antara 10-20 Kg. Ketika Raskin diubah namanya menjadi Bansos Rastra tahun 2017, pemerintah telah menetapkan bahwa setiap Keluarga Penerima Manfaat (KPM) mendapatkan $10 \mathrm{~kg}$ beras berkualitas medium setiap bulannya tanpa dikenakan harga/biaya tebus.

Berbagai penelitian telah dilakukan sejak implementasi Raskin. Hasil studi menunjukkan bahwa penyaluran Raskin kurang efektif (Hastuti dkk., 2008). Sementara itu, pendistribusian Raskin tidak sesuai dengan tujuan yang tercantum dalam buku panduan ataupun dokumen resmi (World Bank, 2012). Dari sisi outcome, Raskin telah berhasil meningkatkan konsumsi pada rumah tangga miskin (Sumarto, Suryahadi dan Widyanti, 2004; Pangaribowo, 2012; Kustianingrum dan Terawaki, 2018). Selain itu, program Raskin juga berdampak pada peningkatan outcome kesehatan anak (Gupta dan Huang, 2018).

Secara empiris program Raskin memang memberikan dampak positif bagi penerima bantuan, tetapi ketepatan sasaran masih menjadi persoalan krusial yang perlu diatasi. Pemerintah pernah berupaya memperbaiki masalah penargetan tersebut melalui penggunaan satu kartu dalam mengakses semua bantuan pemerintah, termasuk Raskin. Dengan menguji coba di 600 desa, ditemukan bahwa penggunaan kartu berhasil menaikkan jumlah beras Raskin yang diterima RTS dan menurunkan harga tebusnya (Banerjee dkk., 2018). Meskipun penerima program Raskin sudah dominan berasal dari rumah tangga miskin, studi Satriawan dan Shrestha (2018) menemukan adanya perbedaan derajat partisipasi rumah tangga miskin antar kelompok pengeluaran, yang diukur dengan kuantitas beras yang dibeli dan frekuensi pembelian beras. Rumah tangga sangat miskin (kelompok 20\% terbawah) memiliki derajat partisipasi yang lebih rendah dibanding rumah tangga kurang miskin (kelompok 20\% teratas). Ini artinya, program Raskin lebih banyak dinikmati oleh rumah tangga kurang miskin dibanding rumah tangga yang paling miskin.

Hal ini menimbulkan pertanyaan lanjutan, apakah pengaruh Raskin terhadap kesejahteraan juga lebih rendah dirasakan oleh rumah tangga yang paling miskin dibanding rumah tangga yang kurang miskin. Studi ini bertujuan untuk mengkaji adanya variasi pengaruh program Raskin terhadap konsumsi beberapa jenis makanan dengan menggunakan sampel rumah tangga penerima Raskin tahun 2014.

\section{TINJAUAN PUSTAKA}

Program Beras Untuk Orang Miskin (Raskin) atau Beras Sejahtera (Rastra) merupakan program pengentasan kemiskinan yang paling lama implementasinya di Indonesia. Sepanjang 21 tahun pelaksanaanya, berbagai penelitian telah dilakukan untuk melihat sejauh mana efektivitas program ini dalam memperbaiki konsumsi rumah tangga miskin di Indonesia.

Literatur empiris tentang Raskin di Indonesia umumnya fokus pada dua hal, yaitu menilai efektivitas penyaluran Raskin (Hastuti dan Maxwell, 2003; Hastuti dkk., 2008; World Bank, 2012; Banerjee dkk., 2018; Satriawan dan Shrestha, 2018) dan menganalisis pengaruhnya terhadap kesejahteraan rumah tangga miskin (Sumarto, Suryahadi dan Widiyanti, 2005; Pangaribowo, 2012; Djamaluddin, 2015; Kustianingrum dan Terawaki, 2018; Gupta dan Huang, 2018; Sadono, 2018).

Hasil penelitian Hastuti dkk. (2008) tentang efektivitas penyaluran Raskin menemukan bahwa implementasi program Raskin kurang efektif, ditandai dengan sosialisasi dan transparansi yang kurang memadai; target penerima, harga, jumlah, dan frekuensi penerimaan beras kurang 
tepat sasaran; biaya pengelolaan program tinggi; pelaksanaan pemantauan belum optimal; dan mekanisme pengaduan kurang berfungsi. World Bank (2012) juga merilis hasil temuanya tentang inefektivitas program Raskin di Indonesia. Penelitian tersebut menemukan bahwa distribusi Raskin tidak selaras dengan tujuan yang sudah ditentukan, seperti: Raskin tidak menargetkan daerah rawan pangan; Raskin tambahan sering tidak diprioritaskan untuk rumah tangga miskin; biaya operasional yang dianggarkan untuk Raskin lebih tinggi daripada program bantuan sosial lainnya, tetapi biaya tata kelola distribusi program tersebut jauh lebih mahal; dan hanya sedikit insentif bagi local implementer untuk membuat Raskin menjadi efektif bagi rumah tangga rentan. Khusus untuk ongkos program yang sangat mahal, hasil studi yang dilakukan oleh Fernandes, Rosengard dan Hanna (2015) merekomendasikan agar mengganti program Raskin dengan program cash transfer karena dampaknya lebih besar dan lebih murah.

Inefektivitas dari program Raskin tentu berimplikasi pada outcomes, terutama pada perbaikan kesejahteraan rumah tangga miskin. Penelitian tentang dampak Raskin terhadap kesejahteraan rumah tangga miskin menunjukkan hasil beragam. Sebagian mengatakan progam tersebut berdampak, namun beberapa penelitian lainnya menyimpulkan tidak berdampak. Sumarto, Suryahadi dan Widyanti, (2004) menemukan bahwa dari sisi konsumsi, program ini berdampak positif karena meningkatkan konsumsi sebesar $4,4 \%$ dan membuat rumah tangga penerima Raskin lebih tidak rentan miskin dibanding rumah tangga bukan penerima.

Dengan menggunakan data the Indonesia Family Life Survey (IFLS), studi Pangaribowo (2012) mengkaji dampak subisidi beras untuk rumah tangga miskin terhadap konsumsi beras. Hasil studi menunjukkan adanya peningkatan konsumsi beras dan makanan pokok pada rumah tangga penerima Raskin. Karena masyarakat membeli beras dengan harga murah, terjadi perubahan pola pengeluaran/konsumsi setelah mereka berpartisipasi dalam program Raskin. Sebelum program Raskin berlangsung, proporsi pengeluaran beras cukup tinggi, terutama ketika harga beras mengalami kenaikan pasca krisis tahun 1998. Namun program beras murah menyebabkan terjadinya pengalihan pengeluaran untuk kepentingan investasi sumberdaya manusia yaitu makanan bernutrisi tinggi (telur, susu, ikan, dan daging), pendidikan, dan kesehatan. Studi Kustianingrum dan Terawaki (2018) juga menemukan bukti adanya pengaruh subsidi beras terhadap asupan kalori untuk rumah tangga yang mengosumsi beras kurang dari $15 \mathrm{~kg}$ per bulan dan rumah tangga yang mengosumsi beras lebih dari $15 \mathrm{~kg}$ perbulan, namun pengaruhnya lebih kecil terhadap asupan karbohidrat bagi rumah tangga dengan konsumsi beras di bawah $15 \mathrm{~kg}$ per bulan.

Meski berdampak positif terhadap konsumsi, program subsidi beras ternyata juga membawa konsekuensi yang tidak diharapkan. Setidaknya ada dua dampak ikutan dari program subsidi beras di Indonesia yaitu naiknya konsumsi adult goods, seperti rokok dan alkohol (Pangaribowo, 2012) dan penurunan pendapatan rumah tangga (Rasyid, 2012; Sadono, 2018). Karena memiliki kelebihan pendapatan akibat penurunan harga beras, rumah tangga miskin mengalihkan sebagian pengeluaran mereka untuk membeli adult goods. Temuan tersebut didukung oleh publikasi BPS bahwa salah satu pengeluaran terbesar rumah tangga miskin pada tahun 2018 adalah rokok. Sementara itu, waktu jam kerja kepala rumah tangga lebih sedikit setelah adanya program subsidi sehingga mempengaruhi pendapatan rumah tangga. Konsekuensi lain juga ditemukan oleh studi Arias dan Carneus (2011) di Haiti, dimana program subsidi beras berhasil menurunkan potensi konflik sosial di Haiti, namun muncul efek samping yaitu naiknya harga beras relatif terhadap harga beras internasional.

Perbaikan pola konsumsi rumah tangga setelah mendapat subsidi beras tidak hanya mempengaruhi status kesehatan orang dewasa, tapi juga memperbaiki kondisi kesehatan anak. Secara rata-rata, anak yang hidup dalam rumah tangga miskin memiliki status kesehatan relatif lebih buruk dibandingkan anak dalam rumah tangga tidak miskin, tidak hanya pada saat dia masih usia anak, tapi hingga mereka tumbuh dewasa (Gupta, Wit dan McKeown, 2007). Dibandingkan dengan rumah tangga non-miskin, bayi yang lahir dari orang tua miskin jauh lebih 
besar risiko kematianya, lebih rawan terkena penyakit kronis (asma), dan berpotensi lebih besar terkena diabetes dan kelebihan berat badan. Hal tersebut terjadi karena orang tua mereka tidak mampu mencukupi kebutuhan nutrisi. Namun studi menunjukkan bantuan subisidi beras berdampak positif terhadap status kesehatan anak dalam jangka panjang (Gupta dan Huang, 2018). Selain itu, orang tua yang mendapatkan bantuan subsidi beras ketika anaknya masih bayi, akan jauh lebih besar dampaknya terhadap outcome kesehatan anak dibandingkan pada orang tua yang mendapatkan bantuan pada saat anaknya sudah dewasa.

Meskipun beberapa penelitian berhasil membuktikan bahwa program subsidi beras untuk rumah tangga miskin berpengaruh terhadap konsumsi nutrisi, karbohidrat, bahkan terhadap perbaikan kualitas sumberdaya manusia, namun penelitan lain justru menemukan fenomena sebaliknya. Ditemukan bukti di daerah perdesaan di India bahwa kenaikan pendapatan karena program subsidi harga makanan mengubah pola konsumsi komoditas biji-bijian dan sumber kalori tertentu yang lebih mahal, dan menurunkan konsumsi biji-bijian kasar yang lebih murah, namun lebih enak rasanya, sumber nutrisi lebih rendah, tetapi tidak berpengaruh pada asupan kalori, protein dan lemak di rumah tangga miskin (Kaushal dan Muchomba, 2013). Studi ini juga membuktikan bahwa program subsidi beras pemerintah India mempengaruhi pasar komoditas pertanian, tapi tidak pada perbaikan nutrisi.

Sementara itu, studi Jensen dkk. (2011) mencoba mencari bukti dampak program subsidi beras terhadap perbaikan nutrisi dengan menggunakan metode randomized controlled trial pada dua provinsi di Cina. Hasilnya, mereka tidak menemukan fakta bahwa subsidi bisa memperbaiki nutirisi rumah tangga miskin, tapi justru berdampak pada penurunan asupan kalori pada salah satu provinsi karena terjadi subtitusi dari makanan subsidi ke jenis makanan yang tidak mengandung nutrisi.

\section{METODE PENELITIAN}

Studi ini menggunakan data yang bersumber dari the Indonesia Family Life Survey (IFLS). Data IFLS merupakan data rumah tangga dan komunitas yang bersifat longitudinal dan merepresentasikan $83 \%$ populasi di Indonesia pada tahun 1993. Survei pertama kali dilakukan pada tahun 1993 (IFLS 1), lalu dilanjutkan berturut-turut pada tahun 1997 (IFLS 2), tahun 1998 (IFLS2+), tahun 2000 (IFLS 3), tahun 2007 (IFLS 4), dan tahun 2014 (IFLS 5). Jumlah observasi IFLS gelombang pertama terdiri dari 7.224 rumah tangga dan sekitar 22.000 individu. Studi ini menggunakan data IFLS 5 dengan unit analisis level rumah tangga. Berbeda dengan studi sebelumnya yang memasukkan observasi penerima dan bukan penerima Raskin (Pangaribowo, 2012; Djamaluddin, 2015; Sadono, 2018), studi ini hanya menggunakan observasi penerima Raskin sebanyak 6.371 rumah tangga berdasarkan data IFLS tahun 2014.

Untuk menghitung perbedaan perilaku konsumsi rumah tangga penerima Raskin pada berbagai kelompok pengeluaran, model estimasi yang digunakan adalah regresi multivariat dengan metode Ordinary Least Square (OLS). Penggunaan regresi multivariat memungkinkan untuk mengontrol sejumlah faktor lain yang secara simultan berpengaruh terhadap variabel dependen. Adapun model dasar regresi multivariat sebagai berikut: $y_{i}=\beta_{0}+\beta_{1} x_{i}+\beta_{2} X_{i}+u_{i}$, dimana $y$ adalah variabel dependen; $x$ adalah variabel independen utama; $X$ adalah sekumpulan variabel kontrol; $u$ adalah error term; $\beta_{0}$, $\beta_{1}, \beta_{2}$ merupakan koefisien regresi. Untuk mengatasi masalah heteroskedastisitas, teknik estimasi menggunakan robust standard error.

Variabel dependen terdiri dari proporsi konsumsi beberapa jenis makanan terhadap total konsumsi dengan mengacu pada studi Pangaribowo (2012). Produk makanan yang digunakan dalam penelitian ini terdiri dari beras, barang kebutuhan pokok, sayuran, telur dan susu, daging dan ikan, dan adult goods (rokok dan alkohol).

Variabel independen utama yang akan diestimasi adalah dummy kelompok rumah tangga berdasarkan pengeluaran per kapita. Rumah tangga penerima Raskin dibagi ke dalam lima kelompok berdasarkan ukuran relatif jumlah pengeluaran per kapita-nya. Sementara itu, pemilihan variabel kontrol juga mengikuti studi 
Pangaribowo (2012), yakni dengan memasukkan karakteristik kepala rumah tangga, karakteristik rumah tangga, dan karakteristik rumah tempat tinggal. Berdasarkan penentuan variabel di atas, maka dirumuskan model regresi multivariat sebagai berikut:

share_konsumsi $i_{i}=\beta_{0}+\beta_{1}$ Dumlpce $_{i}+\beta_{2} X_{i}+u_{i}$,

Dimana share_konsumsi adalah proporsi konsumsi setiap produk makanan terhadap total konsumsi; Dumlpce adalah dummy kategori rumah tangga penerima Raskin berdasarkan kelompok pengeluaran per kapita; $X$ adalah sekumpulan variabel kontrol, terdiri dari karakteristik kepala rumah tangga, karakteristik rumah tango,a, dan karakteristik rumah tempat tinggal; $u$ adalah error term; $\beta_{0}, \beta_{1}, \beta_{2}$ merupakan koefisien regresi.

\section{HASIL DAN PEMBAHASAN}

Studi ini menggunakan 6.371 rumah tangga penerima Raskin pada tahun 2014. Berdasarkan ringkasan statistik pada Tabel 1, rata-rata proporsi pengeluaran beras $11,47 \%$, makanan pokok $12,97 \%$, sayuran $5,4 \%$, telur dan susu $3,15 \%$, daging dan ikan $8,32 \%$, rokok dan alkohol $6,57 \%$.

Tabel 1. Ringkasan Stastistik

\begin{tabular}{|c|c|c|c|c|}
\hline & Rata-rata & Deviasi Standar & Minimum & Maksimum \\
\hline \multicolumn{5}{|l|}{ variabel dependen } \\
\hline proporsi beras & 11.47 & 9.41 & 0 & 65.35 \\
\hline proporsi makanan pokok & 12.97 & 9.74 & 0 & 67.24 \\
\hline proporsi sayuran & 5.40 & 4.10 & 0 & 46.95 \\
\hline proporsi telur dan susu & 3.15 & 3.67 & 0 & 34.13 \\
\hline proporsi daging dan ikan & 8.32 & 6.37 & 0 & 71.27 \\
\hline proporsi rokok dan alkohol & 6.57 & 7.29 & 0 & 58.12 \\
\hline \multicolumn{5}{|l|}{ variabel independen utama } \\
\hline kelompok $<=20 \%$ & 0.20 & 0.40 & 0 & 1 \\
\hline kelompok $>20 \%-40 \%$ & 0.20 & 0.40 & 0 & 1 \\
\hline kelompok $>40 \%-60 \%$ & 0.20 & 0.40 & 0 & 1 \\
\hline kelompok $>60 \%-80 \%$ & 0.20 & 0.40 & 0 & 1 \\
\hline kelompok $>80 \%$ & 0.20 & 0.40 & 0 & 1 \\
\hline \multicolumn{5}{|c|}{ karakteristik kepala rumah tangga } \\
\hline umur & 48.18 & 15.61 & 13 & 101 \\
\hline pria & 0.68 & 0.47 & 0 & 1 \\
\hline menikah & 0.78 & 0.42 & 0 & 1 \\
\hline lama pendidikan & 6.45 & 4.08 & 0 & 18 \\
\hline \multicolumn{5}{|l|}{ karakteristik rumah tangga } \\
\hline jumlah anggota rumah tangga & 3.95 & 1.72 & 1 & 17 \\
\hline tabungan & 0.66 & 0.47 & 0 & 1 \\
\hline kendaraan & 0.20 & 0.40 & 0 & 1 \\
\hline toilet sendiri & 0.76 & 0.43 & 0 & 1 \\
\hline minum air mineral & 0.22 & 0.42 & 0 & 1 \\
\hline bahan bakar gas & 0.63 & 0.48 & 0 & 1 \\
\hline kota & 0.46 & 0.50 & 0 & 1 \\
\hline jawa & 0.61 & 0.49 & 0 & 1 \\
\hline \multicolumn{5}{|c|}{ karakteristik rumah tempat tinggal } \\
\hline lantai tidak layak & 0.61 & 0.49 & 0 & 1 \\
\hline dinding tidak layak & 0.25 & 0.43 & 0 & 1 \\
\hline
\end{tabular}


Sementara itu, Gambar 1 menunjukkan ratarata proporsi setiap jenis produk makanan terhadap total konsumsi yang dirinci berdasarkan kelompok pengeluaran. Besarnya proporsi pengeluaran beras dan makanan pokok berbanding terbalik dengan tingkat kesejahteraan rumah tangga penerima Raskin. Rata-rata proporsi pengeluaran beras pada kelompok rumah tangga yang paling miskin mencapai $15 \%$, sedangkan pada kelompok yang kurang miskin tidak lebih dari $8 \%$. Begitupun pada proporsi konsumsi makanan pokok, kelompok yang paling miskin dan kurang miskin masing-masing sebesar $17 \%$ dan $9,2 \%$. Sebaliknya, besarnya proporsi pengeluaran makanan yang bernutrisi, seperti sayuran, telur dan susu, daging dan ikan berbanding lurus dengan tingkat kesejahteraan rumah tangga penerima Raskin. Rumah tangga yang kurang miskin secara rata-rata memiliki proporsi pengeluaran untuk sayuran, telur dan susu, daging dan ikan, yang sedikit lebih tinggi dibanding kelompok yang paling miskin. Sementara pada rokok dan alkohol, proporsi konsumsi yang relatif tinggi berada pada kelompok menengah. Grafik ini menunjukkan rumah tangga yang paling miskin masih menanggung beban pengeluaran beras dan makanan pokok yang lebih tinggi dibanding rumah tangga yang kurang miskin, meskipun sama-sama menjadi penerima Raskin.

Hasil regresi setiap variabel dependen terhadap variabel independen ditampilkan pada Tabel 2. Proporsi konsumsi pada berbagai jenis komponen pengeluaran dapat dibandingkan antara kelompok rumah tangga yang paling miskin $(20 \%$ terbawah) dan kelompok rumah tangga yang kurang miskin (20\% teratas). Pada model ini, kelompok yang digunakan sebagai basis adalah rumah tangga yang kurang miskin.

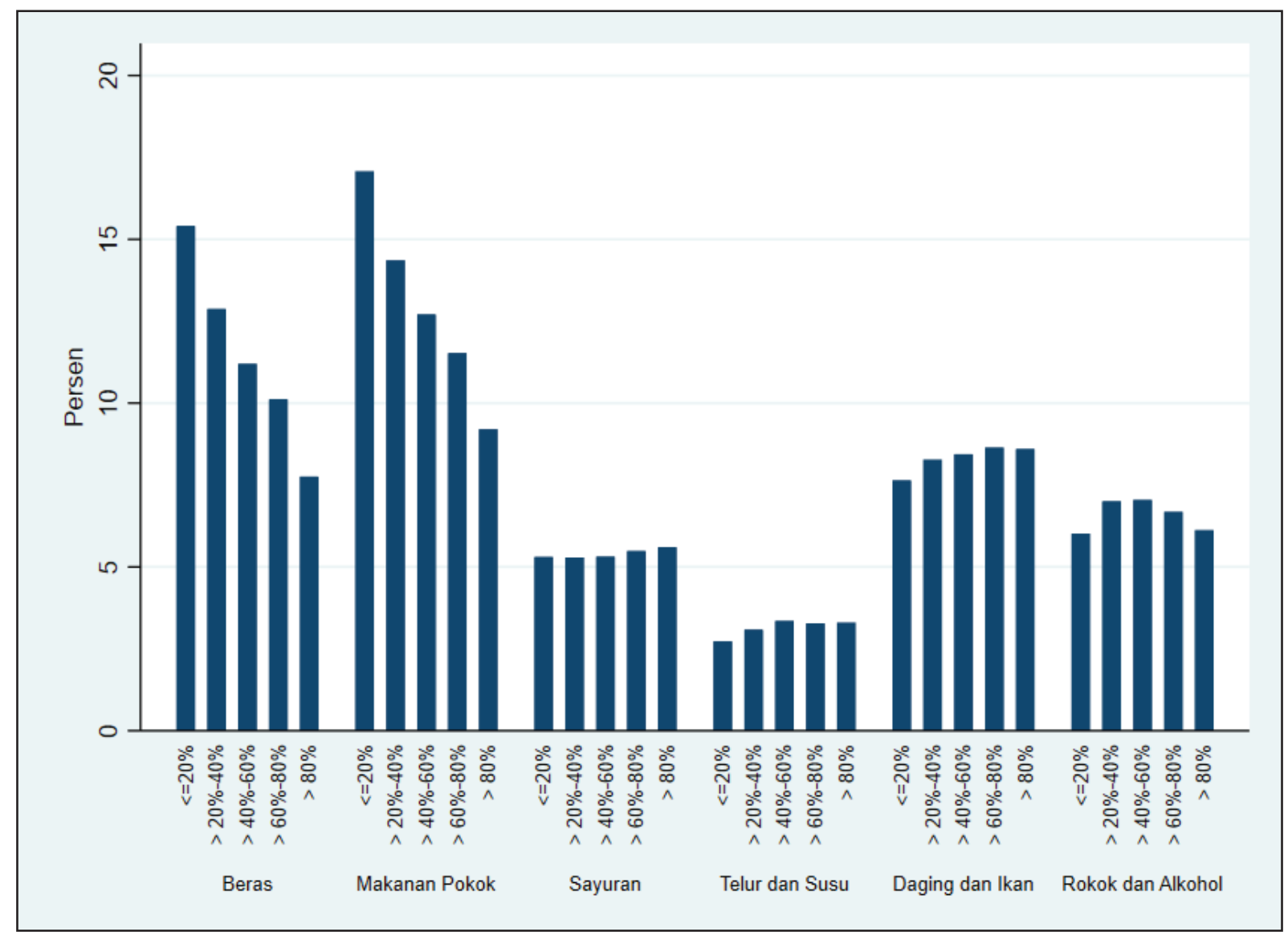

Gambar 1. Rata-rata Proporsi Konsumsi Jenis Makanan terhadap Total Konsumsi Berdasarkan Kelompok Pengeluaran

Sumber: IFLS 5 (diolah) 
Kelompok rumah tangga $20 \%$ terbawah memiliki proporsi pengeluaran beras $6,4 \%$ poin lebih tinggi dibandingkan rumah tangga $20 \%$ teratas. Untuk kelompok lainnya, yaitu rumah tangga yang masuk kelompok $20 \%-40 \%$, $40 \%-60 \%$, dan $60 \%-80 \%$, proporsi konsumsi beras terhadap total konsumsi juga lebih tinggi dibandingkan dengan kelompok 20\% teratas, dengan koefisien masing-masing $4,3 \%, 3,1 \%$, dan $2,2 \%$. Hal ini menunjukkan bahwa kelompok $20 \%$ terbawah secara relatif masih membelanjakan uang yang lebih banyak untuk belanja beras. Sementara pada proporsi pengeluaran barang kebutuhan pokok, kelompok $20 \%$ terbawah secara relatif membelanjakan uang lebih tinggi $6,2 \%$ poin. Hal yang sama juga terjadi pada kelompok 20\%-40\%, 40\%-60\%, dan 60\%-80\%, dimana proporsi konsumsi makanan pokok terhadap total konsumsi juga lebih tinggi dibandingkan dengan kelompok $20 \%$ teratas, dengan koefisien masing-masing $4,1 \%$ poin, $3,1 \%$ poin, dan $2,2 \%$ poin. Pada barang kebutuhan pokok, komponen pengeluaran beras memang berkontribusi paling tinggi dibanding jagung, sagu, dan lainnya, sehingga koefisien pada model proporsi pengeluaran beras dan proporsi makanan pokok tidak jauh berbeda.
Pada makanan bernutrisi, rumah tangga $20 \%$ teratas secara relatif membelanjakan uang lebih tinggi $0,5 \%$ poin untuk telur dan susu dan $1,5 \%$ poin untuk daging dan ikan dibanding rumah tangga $20 \%$ terbawah. Hal ini diduga terjadi karena rumah tangga 20\% teratas mampu melakukan substitusi ke produk lain, seperti telur dan susu, daging dan ikan, karena beban pengeluaran beras berkurang dengan adanya program Raskin. Sebaliknya, sumber daya rumah tangga $20 \%$ terbawah atau bahkan $40 \%$ terbawah lebih banyak dialokasikan untuk belanja beras atau kebutuhan pokok, sehingga kurang mampu melakukan substitusi ke makanan bernutrisi. Oleh karena itu, meskipun program Raskin dapat meningkatkan pengeluaran untuk daging dan ikan, seperti temuan studi Pangaribowo (2012), tetapi temuan studi ini menunjukkan bahwa peningkatan tersebut lebih banyak dirasakan oleh rumah tangga 20\% teratas dibandingkan dengan rumah tangga 20\% terbawah.

Substitusi juga terjadi pada pengeluaran rokok dan alkohol. Kelompok $20 \%$ teratas juga membelanjakan uang lebih tingi $1 \%$ poin dibanding kelompok $20 \%$ terbawah. Ini mengindikasikan adanya substitusi untuk belanja rokok dan alkohol yang lebih tinggi pada kelompok 20\% teratas. Temuan ini didukung oleh studi Pangaribowo (2012) bahwa Raskin meningkatkan konsumsi rokok dan alkohol. 
Tabel 3. Hasil Regresi pada Berbagai Variabel Dependen

\begin{tabular}{|c|c|c|c|c|c|c|}
\hline & beras & makanan pokok & sayuran & telur dan susu & daging dan ikan & $\begin{array}{l}(6) \\
\text { rokok dan } \\
\text { alkohol }\end{array}$ \\
\hline \multicolumn{7}{|c|}{ kelompok pengeluaran: } \\
\hline \multirow[t]{2}{*}{$<=20 \%$} & $6.403^{* * *}$ & $6.277^{* * *}$ & -0.235 & $-0.575^{* * *}$ & $-1.548^{* * *}$ & $-1.051^{* * *}$ \\
\hline & $(0.397)$ & $(0.407)$ & $(0.190)$ & $(0.152)$ & $(0.287)$ & $(0.302)$ \\
\hline \multirow[t]{2}{*}{$>20 \%-40 \%$} & $4.345^{\star \star \star}$ & $4.188^{* * *}$ & -0.264 & -0.238 & $-0.707^{\star \star *}$ & -0.017 \\
\hline & $(0.346)$ & $(0.358)$ & $(0.176)$ & $(0.149)$ & $(0.273)$ & $(0.297)$ \\
\hline \multirow[t]{2}{*}{$>40 \%-60 \%$} & $3.101^{* * *}$ & $3.072^{* * *}$ & -0.248 & 0.009 & -0.406 & 0.211 \\
\hline & $(0.333)$ & $(0.347)$ & $(0.176)$ & $(0.152)$ & $(0.269)$ & $(0.286)$ \\
\hline \multirow[t]{2}{*}{$>60 \%-80 \%$} & $2.270^{* * *}$ & $2.189^{* * *}$ & -0.060 & -0.077 & -0.051 & 0.041 \\
\hline & $(0.319)$ & $(0.330)$ & $(0.174)$ & $(0.146)$ & $(0.273)$ & $(0.273)$ \\
\hline \multirow[t]{2}{*}{ umur } & 0.009 & $0.019^{* *}$ & $0.011^{\star \star *}$ & -0.005 & $0.029^{* * *}$ & $-0.051^{* * *}$ \\
\hline & $(0.009)$ & $(0.009)$ & $(0.004)$ & $(0.004)$ & $(0.006)$ & $(0.007)$ \\
\hline \multirow[t]{2}{*}{ pria } & -0.442 & $-0.493^{*}$ & -0.212 & $-0.327^{\star \star *}$ & -0.026 & $2.590^{* * *}$ \\
\hline & $(0.280)$ & $(0.289)$ & $(0.130)$ & $(0.115)$ & $(0.200)$ & $(0.233)$ \\
\hline \multirow[t]{2}{*}{ menikah } & $1.356^{* * *}$ & $1.561^{* * *}$ & $0.420^{* *}$ & $0.255^{\star}$ & $0.746^{* * *}$ & -0.311 \\
\hline & $(0.348)$ & $(0.357)$ & $(0.166)$ & $(0.140)$ & $(0.263)$ & $(0.290)$ \\
\hline \multirow[t]{2}{*}{ lama pendidikan } & $-0.158^{\star \star *}$ & $-0.175^{\star \star \star}$ & -0.001 & $0.039^{* * *}$ & $0.035^{*}$ & $-0.152^{\star * *}$ \\
\hline & $(0.029)$ & $(0.030)$ & $(0.014)$ & $(0.012)$ & $(0.021)$ & $(0.024)$ \\
\hline \multirow[t]{2}{*}{ jumlah rumah tangga } & $-0.168^{* *}$ & $-0.141^{*}$ & $-0.135^{* * *}$ & $0.137^{* * *}$ & $0.191^{* * *}$ & $0.314^{* * *}$ \\
\hline & $(0.075)$ & $(0.078)$ & $(0.035)$ & $(0.028)$ & $(0.052)$ & $(0.058)$ \\
\hline \multirow[t]{2}{*}{ tabungan } & $-1.806^{\star * *}$ & $-2.017^{\star \star *}$ & -0.033 & -0.014 & $-0.658^{\star * *}$ & 0.159 \\
\hline & $(0.264)$ & $(0.275)$ & $(0.122)$ & $(0.103)$ & $(0.185)$ & $(0.213)$ \\
\hline \multirow[t]{2}{*}{ kendaraan } & $-1.219^{* * *}$ & $-1.269^{\star * *}$ & 0.051 & 0.067 & 0.024 & $-0.752^{* * *}$ \\
\hline & $(0.255)$ & $(0.263)$ & $(0.125)$ & $(0.114)$ & $(0.200)$ & $(0.210)$ \\
\hline \multirow[t]{2}{*}{ toilet sendiri } & $-0.585^{\star *}$ & $-0.546^{*}$ & 0.140 & $0.430^{* \star *}$ & $0.351^{*}$ & $-0.789^{* * *}$ \\
\hline & $(0.286)$ & $(0.294)$ & $(0.131)$ & $(0.106)$ & $(0.193)$ & $(0.224)$ \\
\hline \multirow[t]{2}{*}{ minum air mineral } & $-0.707^{\star \star \star}$ & $-0.927^{\star \star *}$ & -0.138 & 0.020 & 0.216 & 0.274 \\
\hline & $(0.245)$ & $(0.251)$ & $(0.134)$ & $(0.115)$ & $(0.199)$ & $(0.228)$ \\
\hline \multirow[t]{2}{*}{ bahan bakar gas } & $-1.651^{* \star *}$ & $-1.928^{\star \star *}$ & 0.092 & $0.260^{* *}$ & -0.234 & 0.224 \\
\hline & $(0.268)$ & $(0.275)$ & $(0.122)$ & $(0.105)$ & $(0.198)$ & $(0.215)$ \\
\hline \multirow[t]{2}{*}{ kota } & $-0.744^{\star \star *}$ & $-1.013^{\star * *}$ & -0.135 & 0.128 & $-0.473^{\star * *}$ & 0.117 \\
\hline & $(0.231)$ & $(0.238)$ & $(0.109)$ & $(0.099)$ & $(0.170)$ & $(0.190)$ \\
\hline \multirow[t]{2}{*}{ jawa } & $-1.364^{* * *}$ & $-1.341^{* * *}$ & $-0.460^{* * *}$ & $0.508^{\star * *}$ & $-1.178^{* * *}$ & $-0.627^{\star \star \star}$ \\
\hline & $(0.252)$ & $(0.257)$ & $(0.118)$ & $(0.102)$ & $(0.177)$ & $(0.204)$ \\
\hline \multirow[t]{2}{*}{ lantai tidak layak } & 0.334 & $0.448^{*}$ & $0.218^{*}$ & 0.049 & 0.036 & $0.496^{* *}$ \\
\hline & $(0.242)$ & $(0.249)$ & $(0.118)$ & $(0.111)$ & $(0.182)$ & $(0.207)$ \\
\hline \multirow[t]{2}{*}{ dinding tidak layak } & 0.100 & 0.288 & $0.372^{\star * *}$ & 0.163 & $1.309^{* * *}$ & $0.573^{* *}$ \\
\hline & $(0.321)$ & $(0.328)$ & $(0.144)$ & $(0.120)$ & $(0.218)$ & $(0.242)$ \\
\hline \multirow[t]{2}{*}{ konstanta } & $12.759^{* * *}$ & $14.108^{* * *}$ & $5.391^{* * *}$ & $1.848^{* * *}$ & $6.766^{\star * *}$ & $7.739^{* * *}$ \\
\hline & $(0.769)$ & $(0.785)$ & $(0.361)$ & $(0.315)$ & $(0.541)$ & $(0.584)$ \\
\hline Jumlah Observasi & 6,371 & 6,371 & 6,371 & 6,371 & 6,371 & 6,371 \\
\hline R-Kuadrat & 0.136 & 0.149 & 0.013 & 0.024 & 0.037 & 0.064 \\
\hline
\end{tabular}

8 | Jurnal Ekonomi dan Pembangunan Vol 27, No. 2, 2019 


\section{KESIMPULAN DAN SARAN}

Studi ini bertujuan untuk menganalisis variasi pengaruh Raskin terhadap konsumsi makanan rumah tangga pada berbagai kelompok pengeluaran. Temuan studi ini menunjukkan bahwa rumah tangga yang paling miskin memiliki proporsi pengeluaran yang lebih tinggi untuk konsumsi beras dan makanan pokok dibanding rumah tangga yang kurang miskin. sebaliknya, rumah tangga yang kurang miskin justru memiliki proporsi pengeluaran yang lebih tinggi untuk konsumsi makanan yang bernutrisi (telur, susu, daging ikan) dan adult goods (rokok dan alkohol), dibanding rumah tangga yang paling miskin. Hal ini diduga terjadi karena adanya efek substitusi dari bantuan Raskin.

Temuan studi ini menguatkan temuan studi Satriawan and Shrestha (2018) bahwa pada rumah tangga penerima raskin, kelompok rumah tangga paling miskin bepartisipasi lebih sedikit terhadap program Raskin dibanding rumah tangga yang kurang miskin. Hal ini berimplikasi pada outcome Raskin yang dampaknya secara relatif lebih sedikit dirasakan oleh kelompok paling miskin dibanding kelompok yang kurang miskin.

Temuan studi ini menunjukkan perlunya pemerintah memperbaiki sasaran program Raskin, yakni memprioritaskan penyaluran ke kelompok paling miskin. Sumber daya untuk pengentasan kemiskinan memang sewajarnya lebih banyak dialokasikan untuk kelompok paling miskin, karena mereka yang paling menderita dan paling membutuhkan bantuan pemerintah. Dengan perbaikan sasaran pada program Raskin dan progran pengentasan kemiskinan lainnya, taraf hidup rumah tangga yang paling miskin diharapkan dapat meningkat lebih cepat, sehingga mereka mampu terbebas dari kemiskinan. Untuk itu, diperlukan studi lanjutan untuk mengkaji mekanisme penyaluran program Raskin yang lebih tepat sasaran.

\section{DAFTAR PUSTAKA}

Arias, D. and Carneus, M. (2011) 'Unintended Consequences of Food Subsidies: The Case of the Haiti Rice Subsidy', LCSSD Occasional Paper Series on Food Prices.
Banerjee, A. et al. (2018) 'Tangible Information and Citizen Empowerment: Identification Cards and Food Subsidy Programs in Indonesia', Journal of Political Economy, 126(2).

Djamaluddin, S. (2015) How to Ease the Burden of Poor Household? : The Role of Raskin Program.

Fernandes, M. J. G., Rosengard, J. and Hanna, R. (2015) Improving Food Access for Poor Households in Indonesia: Cash Transfer and the Raskin Program Reform.

Gupta, P. and Huang, B. (2018) In-Kind Transfer and Child Development: Evidence from Subsidized Rice Program in Indonesia. Tokyo.

Gupta, R. P.-S., Wit, M. L. de and McKeown, D. (2007) 'The Impact of poverty on the current and future health status of children', Paediatr Child Health, 12(8), pp. 667-673.

Hastuti et al. (2008) Efektivitas Pelaksanaan Raskin. Jakarta.

Hastuti and Maxwell, J. (2003) Beras untuk Keluarga Miskin (RASKIN ): Apakah Program Tahun 2002 Berjalan Efektif? Bukti-bukti dari Bengkulu dan Karawang. Jakarta.

Jensen, R. T. et al. (2011) 'Do consumer price subsidies really improve nutrition?', 93(November), pp. 1205-1223.

Kaushal, N. and Muchomba, F. (2013) How Consumer Price Subsidies Affects Nutrition.

Kustianingrum, W. and Terawaki, T. (2018) 'The Impacts of Rice Price Subsidy on Nutrition Intake of The Poor', in 2nd International Conference on Indonesian Economy and Development, pp. 205-209.

Pangaribowo, E. H. (2012) 'The Impact of "Rice for the Poor " on Household Consumption', in the 56th Australian Agricultural \& Resources Economics Society Annual Conference.

Rasyid, M. (2012) 'Efek Disinsentif Program Raskin Dan Pengaruhnya', Jurnal Ekonomi Pembangunan, 13. 
Sadono, E. D. (2018) 'Impact Evaluation of Raskin Program using Matching Method: Case of IFLS 5', Jurnal Ekonomi dan Kebijakan, 11(1), pp. 207-223.

Satriawan, E. and Shrestha, R. (2018) 'Mistargeting and Regressive Take Up of the Indonesian Rice Subsidy Program', Asian Economic Journal, 32(4), pp. 387-415. doi: 10.1111/ asej.12164.
Sumarto, S., Suryahadi, A. and Widyanti, W. (2004) Assessing the Impact of Indonesian Social Safety Net Programs on Household Welfare and. Jakarta.

World Bank (2012) Raskin Subsidized Rice Delivery: Social Assistance Program and Public Expenditure Review 3. Jakarta. 